\title{
Litter Characteristics and Pododermatitis Incidence in Broilers Fed a Sorghum-Based Diet
}

ISSN 1516-635X Jul - Sept 2014 / v.16 / n.3 / 291-296

http://dx.doi.org/10.1590/1516-635x1603291-296

\section{-Author(s)}

Carvalho CMC

Litz $\mathrm{FH}^{\prime}$

Fernandes EA $\mathrm{A}^{\prime \prime \prime}$

Silveira MM"

Martins JM da S"

Fonseca LA"

Zanardo JA'

Graduate (Ph.D) student in Animal Production- Universidade Federal de Uberlândia$-M G$

" Graduate (M.Sc.) student in Animal Production -Universidade Federal de Uberlândia-UFU

III Professor, School of Veterinary Medicine, Universidade Federal de Uberlândia-UFU

Iv Professor at Faculdade Presidente Antônio Carlos-UNIPAC

\section{Mail Address}

Corresponding author e-mail address: A. J. Piantino Ferreira

Department of Pathology, School of Veterinary Medicine, University of Sao Paulo, Rua João Angelo Schiavinato, 2270, apto 301, Uberlândia, Brazil CEP 38408272

E-mail: carollcaires@yahoo.com.br

\section{-Keywords}

Turkey, Enteritis, Viruses, Poults, Diagnosis, calcium, environmental impact, phosphorus.

\section{ABSTRACT}

The aim of this study was to evaluate the incidence of footpad dermatitis and quality of broilers litter fed with sorghum grain and diets based in corn. It was used 544 male and female chicks, distributed in a completely randomized design with two treatments and eight replications. The chicken feed was formulated and produced from corn, soybean meal and sorghum grain. In the formulation were kept constant levels of energy and protein in accordance with the following treatments: A. Control (diet based on corn and soybean meal); B. Grain sorghum (Whole Sorghum + soybean meal). At 35 and 42 days were evaluated mineral matter (A \%), calcium (Ca\%), phosphorus (P\%), $\mathrm{pH}$ and dry matter (DM \%) of the poultry litter. To evaluate the footpad dermatitis were evaluated eight feet per treatment by visual analysis. At 35 and 42 days of age DM \% MM (\%), Ca (\%) P (\%) and pH of poultry litter no difference ( $p>0.05)$ was found between the treatments and the type of ingredient in the birds' diet is not related ( $p>0.05)$ with the incidence of footpad dermatitis. The incidence of footpad dermatitis and the quality of the litter weren't influenced by the type of the ingredient used in diet.

\section{INTRODUCTION}

In the livestock industry, poultry production has made expressive progress. Nutrition has significantly contributed for that development searching to improve dietary nutrient utilization (Rodrigues, 2003).

Feed accounts for $75 \%$ of total broiler production costs. Therefore, once environmental comfort and health are ensured, it is the role of nutrition to feed birds sufficient nutrients to supply their maintenance and growth requirements. The diets must present good quality, low nutrient loss in the excreta, as well as low cost.

According to Garcia et al. (2005), sorghum grain is an alternative feedstuff to corn and may allow significant reduction in feed costs, particularly during times of the year when the cost of broilers fed cornbased diets is high.

Litter characteristics, such as $\mathrm{pH}$, moisture, and mineral content, may change as a function of feed, management practices, and rearing environment. Environmental control has a strong impact on broiler quality and productivity, and it is essential for the management of broiler houses. The functions of the litter are to absorb humidity, dilute urates and feces, thermal insulation, as well as to provide soft bedding, thereby preventing breast blisters and footpad lesions (Hernandes \& Cazetta, 2001). Footpad health has been proposed as one of the best indicators of broiler welfare.

Brazil has exported broiler feet to East Asia for at least 20 years. Feet represented the largest share $(61.76 \%)$ of poultry imports by China in 
2008. Feet trade is even more important to Brazil as it accounts for $82.57 \%$ of poultry products exported to China (Zhang, 2009), thereby highlighting the relevance of identifying feet lesions that could result in their downgrading (Santos et al., 2002).

The objective of this study was to evaluate the incidence of pododermatitis and litter quality of broilers fed diets based on sorghum grain or corn.

\section{MATERIALS AND METHODS}

\section{Birds and experimental design}

The experiment was carried out on the poultry experimental farm of Faculdade Presidente Antônio Carlos-UNIPAC, Uberlândia, state of Minas Gerais, Brazil, between April and June of 2013. The experimental procedures were approved by the Committee of Ethics of that institution under protocol number CEUA/UNIPAC 019/13.

In the experiment, 544 male and female Cobb broilers were distributed according to a completely randomized experimental design into two treatments with eight replicates each. Birds were distributed into 16 pens, with 34 birds each at a density of 12 birds/ $\mathrm{m}^{2}$. New wood-shavings litter covered the floor pens.

\section{Diets}

Feed and water were suppliedad libitum during the entire experiment.The lighting program, using both natural and artificial light, was divided in three phases: $22 \mathrm{~h}$ of light between one and seven days of age, $10 \mathrm{~h}$ of light between eight and 21 days of age, and $23 \mathrm{~h}$ of light between 22 and 42 days of age. The average minimal and maximal house temperatures were daily recorded, and presented minimum and maximum values of $20^{\circ} \mathrm{C}$ and $27.58{ }^{\circ} \mathrm{C}$, respectively. Birds were submitted to the management practices that are typically applied in commercial farms of that region.

Feeds were composed of corn, whole sorghum, soybean meal, soybean oil, dicalcium phosphate, limestone, salt, vitamin-mineral premix, and supplemental amino acids (DL-methionine, L-lysine, and L-threonine). Feeds were formulated to supply the nutritional requirements proposed by Rostagno (2011). Table 1 shows the ingredients and nutritional compositions of the experimental diets. The following treatments were evaluated: treatment $A(T A)$, diet based on corn and soybean meal, and treatment $B$ (TB), diet based on whole grain sorghum and soybean meal.
Table 1 - Composition of the starter (1-28 days) and finisher (29-42 days) experimental diets.

\begin{tabular}{lcccc}
\hline Feedstuff & \multicolumn{2}{c}{ Starter (\%) } & \multicolumn{2}{c}{ Finisher (\%) } \\
\hline & TA & TB & TA & TB \\
\hline Corn grain & 52.31 & - & 60.81 & - \\
\hline Soybean meal & 37.33 & 34.63 & 25.11 & 25.10 \\
\hline $\begin{array}{l}\text { Whole-grain } \\
\text { sorghum }\end{array}$ & - & 53.94 & - & 58.24 \\
\hline Soybean oil & 2.15 & 3.23 & 7.0 & 9.70 \\
\hline Premix & 5.0 & 5.0 & 5.0 & 5.0 \\
\hline $\begin{array}{l}\text { Dicalcium } \\
\text { phosphate }\end{array}$ & 1.76 & 1.64 & 1.28 & 0.87 \\
\hline Limestone & 1.03 & 1.15 & 0.37 & 0.63 \\
\hline Salt & 0.38 & 0.38 & 0.40 & 0.42 \\
\hline & Nutritional composition & & \\
\hline ME (Mcal/kg) & 2.800 & 2.800 & 3.287 & 3.287 \\
\hline CP (\%) & 21.5 & 21.5 & 17.3 & 17.3 \\
\hline Calcium (\%) & 0.96 & 0.96 & 0.55 & 0.55 \\
\hline Available P (\%) & 0.43 & 0.43 & 0.34 & 0.26 \\
\hline Sodium (\%) & 0.17 & 0.17 & 0.18 & 0.18 \\
\hline M Fango & & & & \\
\hline
\end{tabular}

'Mix Frango engorda SAA 4kg - composition/kg feed - Vit-A 9,000IU; D3 1,600IU; E 14mg; folic acid $300 \mathrm{mcg}$; calcium pantothenate $9 \mathrm{mg}$; biotin $50 \mathrm{mcg}$; niacin $30 \mathrm{mg}$; pyridoxine $1.8 \mathrm{mg}$; riboflavin $4 \mathrm{mg}$; thiamin 1mg; B12 $12 \mathrm{mcg} ; \mathrm{K} 1.5 \mathrm{mg}$; Se $250 \mathrm{mcg}$; choline 219mg; Cu 9mg; Zn 60mg; I 1mg; Fe 30mg; Mn 60mg; growth promoter $385 \mathrm{mg}$; coccidiostat $550 \mathrm{mg}$; antioxidant $120 \mathrm{mg}$.

On days 35 and 42, litter samples were collected at three different points of each pen of each treatment, avoiding the areas close or below the feeder and drinker, andsubsequently analyzed for dry matter (DM $\%)$, ash (A \%), calcium (Ca \%), and phosphorus (P \%) content and pH (Silva \& Queiroz, 2009).

\section{Pododermatitis evaluation}

Eight feet per treatment, totaling 16 feet, were assessed for pododermatitis lesions on days 35 and 42.Pododermatitis lesions were evaluated using the methodology proposed by Martrenchar (2001). Lesions were scored as: 1 , lesion covers less than $25 \%$ of the footpad; 2 , lesion coverts $26-50 \%$ of the footpad; and 3, lesion covers more than $50 \%$ of the footpad (Figure 1).

\section{STATISTICAL ANALYSIS}

Data were submitted to analysis of variance and means were compared by the test of Tukey at $5 \%$ significance levels, using Assistat statistical package (Silva, 2009).Pododermatitis scores were evaluated by the Chi-square test of Action $®$ statistical software program (R Development Core Team, 2008). 


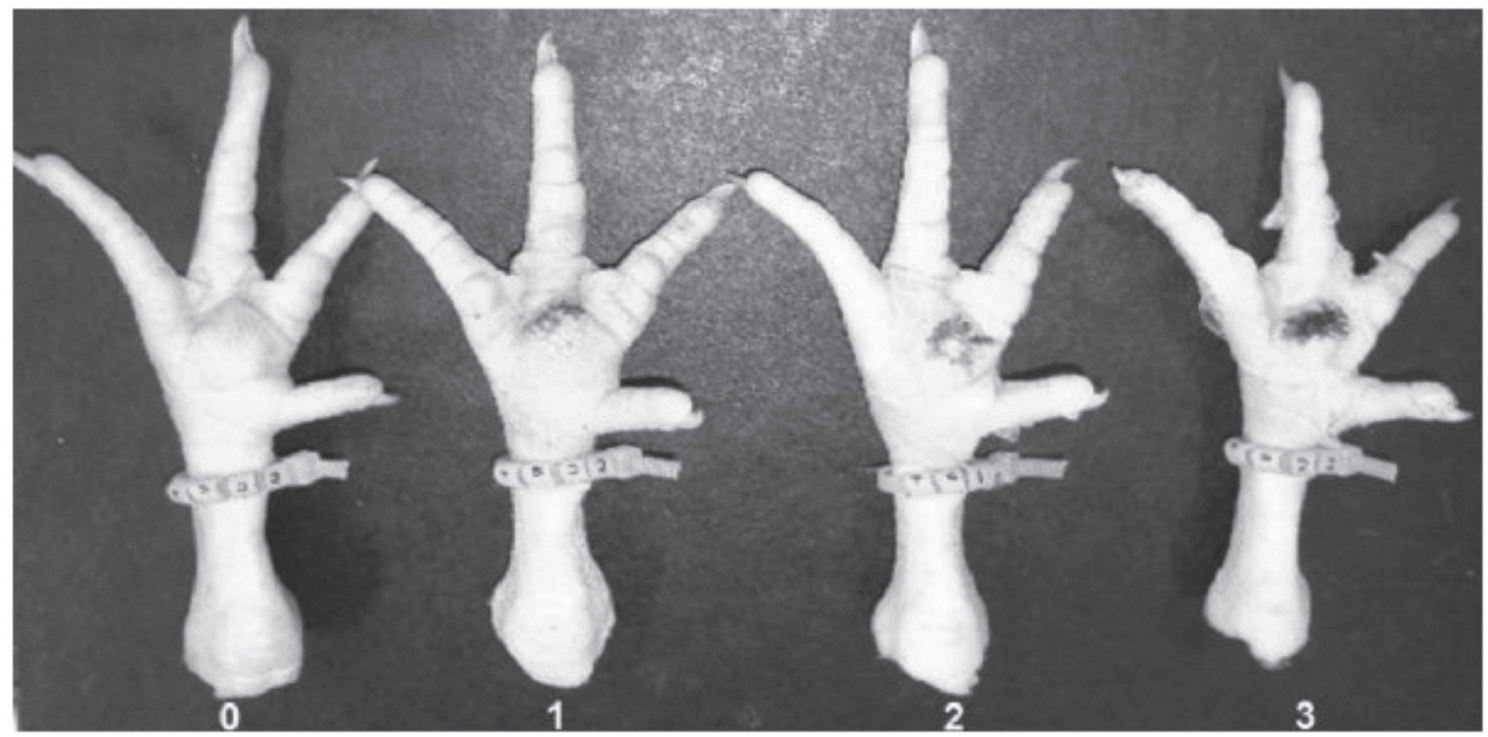

Figure 1 - Broilers feet classified according to footpad lesion score. Source:(Martrenchar, 2001)

\section{RESULTS}

Litter DM (\%), A (\%), Ca (\%), P (\%), and pH were not significantly influenced by the treatments on day 35 or 42 (Tables 2 and 3). These results showed that the litter of broilers feds the diet based on sorghum grain presented the same characteristic as that of broilers fed the corn-based diet. Dry matter, Ca, and $\mathrm{P}$ litter content were similar between treatments and were within acceptable levels, thereby ensuring less environmental pollution. Litter $\mathrm{pH}$ values were close to neutral $\mathrm{pH}$, which prevent ammonia volatilization.

Table 2 - Litter dry matter (DM\%), ash (A\%), calcium $(\mathrm{Ca} \%)$, phosphorus (P\%) and $\mathrm{pH}$ evaluated when broilers were 35 days of age.

\begin{tabular}{lccccc}
\hline Treatments & $\mathrm{DM} \%$ & $\mathrm{~A} \%$ & $\mathrm{Ca} \%$ & $\mathrm{P} \%$ & $\mathrm{pH}$ \\
\hline Corn & 53.04 & 20.24 & 2.65 & 0.5968 & 8.26 \\
\hline Sorghum & 50.25 & 19.64 & 2.36 & 0.5023 & 8.45 \\
\hline $\mathrm{CV}(\%)$ & 3.15 & 13.05 & 12.17 & 20.00 & 3.70 \\
\hline P value & 0.1141 & 0.1250 & 0.2271 & 0.2786 & 0.1152 \\
\hline
\end{tabular}

Means followed by different letters in the same column are different by the test of Tukey at $5 \%$ significance level.

Table 3 - Litter dry matter (DM\%), ash (A\%), calcium $(\mathrm{Ca} \%)$, phosphorus $(\mathrm{P} \%)$ and $\mathrm{pH}$ evaluated when broilers were 42 days of age.

\begin{tabular}{llllll}
\hline Treatments & $\mathrm{DM} \%$ & $\mathrm{~A} \%$ & $\mathrm{Ca} \%$ & $\mathrm{P} \%$ & $\mathrm{pH}$ \\
\hline Corn & 43.24 & 22.14 & 2.62 & 0.67 & 8.07 \\
\hline Sorghum & 42.93 & 22.27 & 2.71 & 0.53 & 7.87 \\
\hline $\mathrm{CV}(\%)$ & 6.11 & 16.91 & 10.14 & 18.35 & 4.66 \\
\hline P value & 0.2013 & 0.2381 & 0.1771 & 0.1177 & 0.1430
\end{tabular}

Means followed by different letters in the same column are different by the test of Tukey at $5 \%$ significance level.
Pododermatitis scored on days 35 and 42 show that feedstuff is not related ( $p>0.05$ ) with the incidence of pododermatitis. The low litter DM content obtained in both treatments justifies the low incidence of pododermatitis observed. These results show that whole grain sorghum is a viable alternative to corn in the diet in terms of footpad lesions and litter quality.

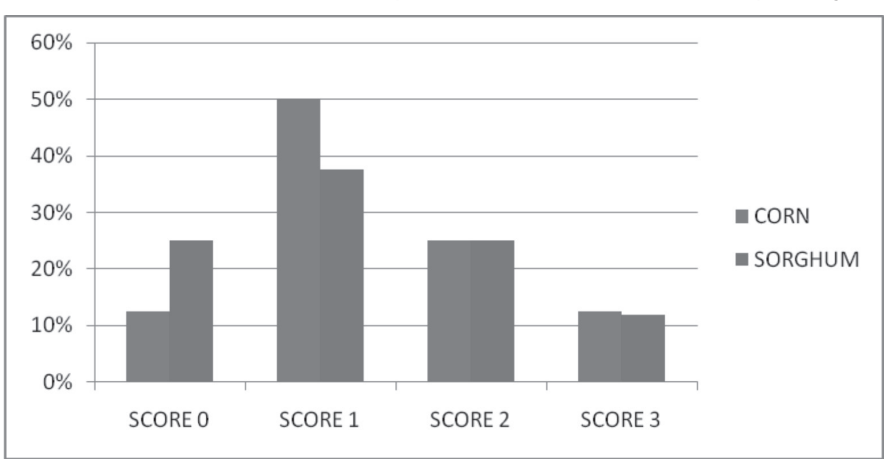

Figure 2 - Pododermatitis classification of 35-day-old broilers. $p$-value $=0.5$

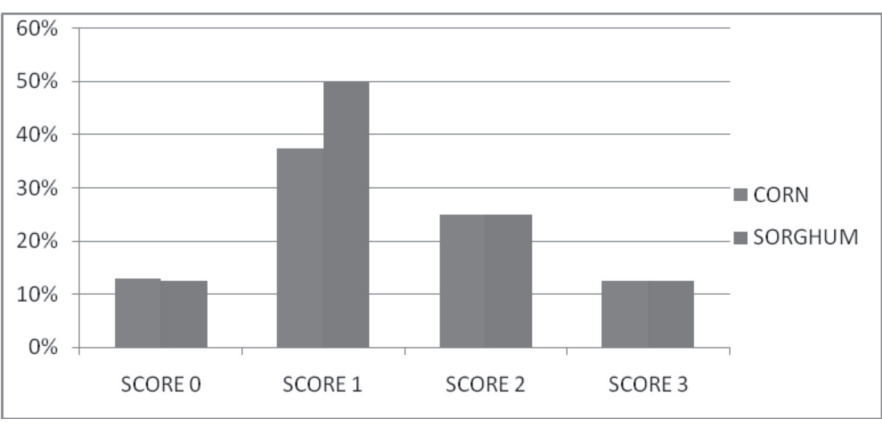

Figure 3 - Pododermatitis classification in 42-day-old broilers. $p$-value $=1$

\section{DISCUSSION}

Litter quality and footpad lesions need to be evaluated when different types of diet are offered. 
According to Garcia et al. (2011) several factors may affect litter quality in broilers houses, such as feed composition or type, litter material, time birds remain on the litter, bird density per area, and environmental temperature. Mayne et al. (2006) and Youssef et al. (2008) mention several studies that indicate that high litter humidity may induce pododermatitis, independently of other factors. The studies of Abd El-Wahab (2012) showed that broilers reared on litter with $65 \%$ humidity presented higher pododermatitis scores than those reared on litter with 35 and 50\% humidity.

Oliveira et al. (2002) showed that litter DM content and footpad lesions were not influenced by bird density (10 or 14 birds $/ \mathrm{m}^{2}$ ) when corn-based diets were offered.In that study, litter dry matter was $62 \%$, differently from the results of the present study. However, the present results are consistent with the findings of Lopes et al. (2005), who obtained $42 \%$ litter DM, using corn-based diet.

Payne (1998) showed that calcium and phosphorus content in broiler wood-shavings litter may range between 0.6-3.9 and 0.8-6.1, respectively. The results of the present study are consistent with those findings. Silva (2006) determined $1.22 \%$ calcium and $1.76 \%$ phosphorus in wood-shavings litter of broiler fed corn diets.

Oliveira et al.(2003) observed that the pH of woodshavings litter of 42-day-old broilers fed a corn-based diet was 8.04, which is close to the value obtained in the present study.Litter $\mathrm{pH}$ directly influences air ammonia levels. Ammonia volatilization is low when $\mathrm{pH}$ is lower than 7 and increases with pH (Reece et al., 1979).

Litter quality has a strong influence on pododermatitis incidence. According to Jong \& Hanr (2012), diet formulation based on digestible amino acids, the knowledge on the composition of the feedstuffs, and optimal sodium and potassium levels in the feed may reduce the incidence of that disease and improve broiler welfare. This should be taken into account as animal welfare legislation will become increasingly strict.

Conde et al. (2005) evaluates litter humidity and pododermatitis in broilers fed diets based on corn, soybean meal, poultry offal meal, or corn gluten meal. The results showed that birds fed diets containing corn gluten meal presented less pododermatitis lesions and the humidity of their litter was lower compared with those fed the other diets.

As there are few studies on these subjects, further research should be carried out to elucidate the influence of diet on litter composition, and consequently, its effect on the incidence of pododermatitis and on animal welfare.

\section{CONCLUSIONS}

The evaluated feedstuffs did not influence pododermatitis or litter quality in this study.

\section{REFERENCES}

Abd El-Wahab, A., Visscher, CF., Beineke, A., Beyerbach, M., Kamphues, J. Experimental studies on the effects of different litter moisturecontents and exposure time to wet litter on development andseverity of foot pad dermatitis in young fattening turkeys. Archiv fur Geflügelkunde 2012;76:55-62.

Conde ORA, Olmos AR, Gallo BB, Bortolini TCK, Silva GX da. Avaliação de lesões de pododermatite e umidade de cama de frangos de corte consumindo dietas vegetarianas suplementadas com complexo enzimático. In: Anais do 17th Salão de Iniciação Científica; 2005; Porto Alegre, Rio Grande do Sul. Brasil.

Garcia RG; Paz ICLA, Caldara FR. Papel da cama na produção e bem estar de frangos de corte. Revista Avisite 2011:47:46-50.

Garcia RG, Paz ICLA, Caldara, F.R Avaliação do desempenho e de parâmetros gastrintestinais de frangos de corte alimentados com dietas formuladas com sorgo alto tanino e baixo tanino. Ciência e Agrotecnologia 2005;29:42-47

Hernandes R, Cazetta JO. Métodos impleseacessível para determinar amônia liberada pela cama aviária. Revista Brasileira de Zootecnia 2001:30:824-829.

Jong I, Harn, IJV. Técnicas de Manejo para a redução de pododermatite em frangos. 2012 [cited 2013 Out 17]. Available from: www.avigen.com.

Lopes DCN, Maier JC, Anciuti MA, Krabbe EL, Silva RAG, Silva LM, Silveira MHD, Nunes PM, Rutz, F. Avaliação do teor de umidade da cama de frangos de corte alimentados com diferentes fontes de sódio na dieta. Anais do 21th Congresso de Iniciação Científica; 2005; Pelotas, Rio Grande do Sul. Brasil.

Martrenchar A, Boilletot E, Huonnic D, Pol f. Risk factors for foot pad dermatitis in chicken and turkey broiler in France. Preventive Veterinary Medicine 2001;52:213-226.

Mayne RK, Hocking, PM,Else, RW. Foot pad dermatitis develops at an early age in commercial turkeys. British Poultry Science 2006;47:36-42.

Oliveira JE, Sakomura NK, Figueiredo NA, Jucas Junior J, Santos TMB. Efeito do isolamento térmico de telhado sobre o desempenho de frangos de corte alojados em diferentes densidades. Revista Brasileira de Zootecnia 2000;29:1427-1434

Oliveira MC, Carvalho ID. Rendimento e lesões em carcaça de frangos de corte criados em diferentes camas e densidades populacionais. Ciência Agrotécnica 2002,26:1076-1081

Oliveira, MC, Gourlart, RB, Silva JCN. Efeito de duas densidades e dois tipos de cama sobre a umidade da cama e a incidência de lesões na carcaça de frango de corte. Ciência Animal Brasileira 2003;3:7-12.

Payne, VW. Management, treatment and utilization of poultry litter with respect to environmental protection. Anais do Simpósio Internacional sobre Ambiência e Sistemas de Produção Avícola; 1998; Concórdia, Santa Catarina. Brasil. p.182-193. 
Reece FN, Bates BJ, Lott BD. Ammonia control in broiler houses. Poultry Science 1979;58:754-755

R Development Core Team. R: A language and environment for statistical computing. Vienna: R Foundation for Statistical Computing; 2005. Available from: http://www.R-project.org.

Rodrigues PB, Rostagno H, Albino LFT, Gomes PC, Barboza WA, Toledo RS. Desempenho de frangos de corte, digestibilidade de nutrientes e valores energéticos de rações formuladas com vários milhos, suplementadas com enzimas. Revista Brasileira de Zootecnia 2003;32:171-182.

Rostagno HS, Albino LF, Donzele JL, Gomes PC, Oliveira RF, Lopes DC, Ferreira AS, Barreto SL. Tabelas brasileiras para aves e suínos: composição dos alimentos e exigências nutricionais. Viçosa: UFV; 2011. 141p

Silva FAS, Azevedo CAV. Principal Components Analysis in the Software Assistat - Statistical Attendance. Proceedings of the $7^{\text {th }}$ World Congress on Computers in Agriculture; Reno, Nevasca. Estados Unidos: American Society of Agricultural and Biological Engineers; 2009.

Silva DJ, Queiroz CA. Análise de alimentos: métodos químicos e biológicos 3rd ed. Viçosa: UFV; 2009. 233p.

Silva YL, Rodrigues PB, Freitas, RTF, Bertechini AG, Fialho ET, Fassani EJ، Pereira CR. Redução de proteína e fósforo em rações com fitase para frangos de corte no período de 1 a 21 dias de idade. Desempenho e teores de minerais na cama. Revista Brasileira de Zootecnia 2006;35:840-848

Youssef IMI, Westfahl C, Beineke A, Kamphues J. Experimental studies in turkeys on effects of litter quality and feeding on development and intensity of foot pad dermatitis. Proceedings of the 12th Congress of the European Society of Veterinary and Comparative Nutrition; 2008; Vienna. Austria. p 138. 
